 and Development
}

\section{Density of Indian Grey Hornbills (Ocyceros birostris) in and Around Haveri}

\section{Narayan Ramappa Birasal}

Zoology Department, KLE Society's Gudleppa Hallikeri College, Haveri - 581 110, Karnataka State, India

*Corresponding Author: Narayan Ramappa Birasal, Associate Professor, Zoology Department, KLE Society's Gudleppa Hallikeri College, Haveri - 581 110, Karnataka State, India, Tel: +9194491 22732; E-mail: nrbirasal@gmail.com

Received date: Apr 08, 2014, Accepted date: May 23, 2014, Publication date: May 29, 2014

Copyright: ( 2014 Birasal NR . This is an open-access article distributed under the terms of the Creative Commons Attribution License, which permits unrestricted use, distribution, and reproduction in any medium, provided the original author and source are credited.

\begin{abstract}
Indian Grey Hornbill (Ocyceros birostris) prefers dry deciduous forests, but these habitats are subjected to maximum anthropogenic disturbances. Habitat destruction is the major cause of disturbance for the hornbills population. Indian Grey Hornbill is a fairly common, mostly arboreal found throughout India. But it is not common to be sighted in towns. The regular observations for Indian Grey Hornbill was made during summer and early monsoon season in and around Haveri for two decades (March 1994 to July 2013). As hornbills depend on tree cavities for nesting, search for nest cavities was carried out. Prior to road widening works, density of these birds was high on the trees of highways. This study evaluated that, with the removal of trees in the name of development, the number of these birds increased in the recent months in Haveri town and this is due to suitable environment available for their survival.
\end{abstract}

Keywords: Arboreal bird: Indian Grey Hornbill: Urban environment: Breeding behaviour

\section{Introduction}

Hornbills (family Bucerotidae) are one of the most recognizable groups of birds in the Old World tropics. There are 54 species of hornbills in the world [1] and nine species occur in India. The Indian Grey Hornbill Ocyceros birostris, also known as Common Grey Hornbill, is reported to occur in India, Pakistan and Nepal [2]. In India it is distributed throughout the country, excepting for Malabar, parts of Rajasthan and Assam [3]. In southern India, this species is reported to occur in the dry deciduous tracts of the Eastern Ghats and foothill forests of the Western Ghats[4].

The species is found mainly on the plains up to about 2000 feet. It is found from the foothills of the Himalayas southwards bounded on the west by the Indus system and the Gangetic delta on the east. It may make local movements in the drier western region. It is found mainly on the plains up to about $1400 \mathrm{~m}$ and does not overlap much with the Malabar Grey Hornbill of the Western Ghats.

Hornbills often show high nest-site fidelity, returning to the same nest cavity year after year [5]. Hornbills are secondary cavity nesters, using natural cavities or those excavated by other birds (6). The breeding habits of hornbills are unique in that the female seals herself into a nest cavity and leaves only a narrow slit through which the male passes her food until the nesting period is completed [1].

According to Balasubramanian et al. [4], this species is common in the Eastern Ghats and occasional in the Western Ghats. Breeding behaviour of Indian Grey Hornbill in Eastern Ghats is reported in 2010 [7]. Reports have appeared on breeding aspects in Nagpur, central India [8] and on the restoration initiatives of the Indian Grey Hornbill habitats in Sathyamangalam wildlife sanctuary [9].

Grand wildlife of Karnataka state was concentrated in a few forest pockets in and around Western Ghats [10]. Hornbills require huge trees with large girth for nesting and hence they are mostly confined to primary forests. Threat to forests directly affect the survival of frugivorous birds such as Hornbills [11]. This species has been reported locally extinct from Kathiawar region, including Gir foest and it is likely to go extinct in several other regions due to habitat destruction and other human interferences [6].

Birds, to a great extent are economically beneficial; they are also of course, scientifically interesting and aesthetically delightful, our task, dispassionately and objectively, is to determine the facts (12). Birds have fascinated man for their ability to fly in air and for their exquisite colouration. They have a role to play in the ecosystem as potential pollinators and scavengers, indeed rightly called bio-indicators (13). India being megadiversity centre, harbours 1,200 species of birds. Recently, with the increased consciousness for biodiversity census and monitoring, many new species were discovered or some are redescribed. This aspect prompted me to make the observations for the presence of Indian Grey Hornbill in and around Haveri town.

\section{Climate of the Study Area}

The town is found at an altitude of $552.9 \mathrm{~m}$ AMSL. The geographical location of the town is Latitude: $14^{\circ} 55^{\prime} 0 \mathrm{~N}$, Longitude: $75^{\circ} 40^{\prime} 0 \mathrm{E}$. The average atmospheric temperature of the area ranges between the maximum $33^{\circ} \mathrm{C}$ and the minimum $25^{\circ} \mathrm{C}$. It begins to increase steadily towards the end of February till May, when the maximum day temperature of the atmosphere is about $33^{\circ} \mathrm{C}$ and the mean daily minimum is about $25^{\circ} \mathrm{C}$. At times, the day temperature may shoot up to $38^{\circ} \mathrm{C}$ on certain days. The relative humidity is generally high throughout the year and more particularly so during the South-West monsoon months (June - September). March and April are the arid months with $30-40 \%$ relative humidity while it is as high as $78 \%$ during July-August, after which it decreases gradually up to November and rapidly thereafter till the end of April.

There are no well defined discernible seasons, though summer, rainy and winter seasons are mentioned in folk-lore. In fact, the area exhibits only two seasons, viz the summer starting from February and lasting till June and the rainy season beginning in June and lasting till 
Citation: Birasal NR (2014) Density of Indian Grey Hornbills (Ocyceros birostris) in and Around Haveri. J Biodivers Biopros Dev 1: 110. doi:

Page 2 of 6

October. In reality, South Western part of India which includes Karnataka state has some "summer rains" (rainy season itself occurs during the summer), whereas the states like Tamil Nadu (also South Western part of India) has "winter rains". November and generally December are usually cool and arid months in North Karnataka. Heavy rains occur during June, July and August. On an average there are 100 rainy days (having the rainfall of $1 \mathrm{~mm}$ to $20 \mathrm{~mm}$ or even more per day) per year in the district.

\section{Methodology}

Indian Grey Hornbills breed from March to July [14] thus covering the entire summer months and early monsoon. Observations for Indian grey hornbills found on road sides at four spots were observed once in a month (Sunday's of every month) during breeding season from March 1994 to July 2013.
Schedule of visit planned was

(1) First Sunday : spot near Aladakatti village on Hanagal - Haveri road (Figure 1).

(2) Second Sunday : Spot near Devagiri cross on Pune - Bangalore national highway $\left\{\mathrm{NH}_{4}\right\}$

(3) Third Sunday: Spot near KEB grid in Haveri town and

(4) Fourth Sunday : Spot near Ayurvedic college in Haveri town (Map). Observations for the hornbill activity were made using binoculars. Sightings were recorded whilst the observer was either walking slowly or sitting concealed at a vantage point for morning 2 hours ( 7 am to $9 \mathrm{am}$ ) on every Sunday.

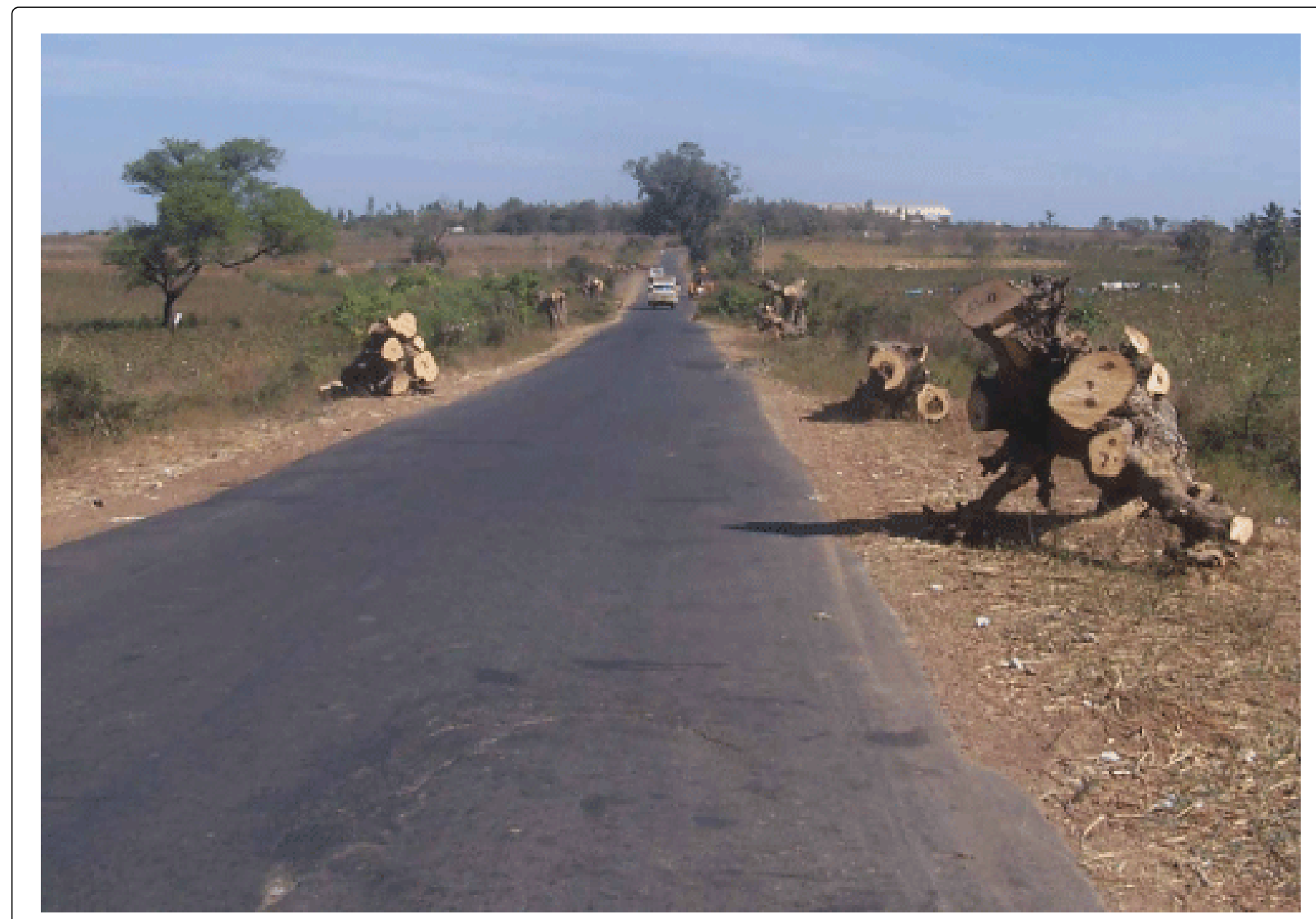

Figure 1: Stumps found after razing the trees on roadsides of Haveri - Hanagal highway.

\section{Observations}

Density of Indian Grey Hornbills from March 1994 to July 2010 was high on the trees found at spot 1 . On an average per year $78.05 \%$ of Indian grey hornbills were sighted from 1994 to 2010 at spot 1 . Indian grey hornbills were sighted by the author in large numbers from March 1994 to July 2000 at spot 2 on the roadside trees of Pune -
Bangalore National Highway. On an average per year $59.71 \%$ of Indian grey hornbills were sighted from 1994 to 2000 at spot 2.

But the trees on Pune-Bangalore road have been removed systematically by the National Highway Authority of India (NHAI) for the development of four-lane highway works (Golden Quadrilateral project of the then Union government). Old trees have also been removed for road widening from Hanagal to Haveri. Prior to the 
Citation: Birasal NR (2014) Density of Indian Grey Hornbills (Ocyceros birostris) in and Around Haveri. J Biodivers Biopros Dev 1: 110. doi:

Page 3 of 6

execution of both these roads, the density of Indian grey hornbills was not high in Haveri town.

But due to destruction of thousands of old avenue trees in the name of development, it appears that Indian grey hornbills have shifted from the trees of both highways to old trees found in and around Haveri town (at spot $3 \& 4$ ). On an average per year $65.34 \%$ of Indian grey hornbills were sighted from 2011 to 2013 at spot 3. On an average per year $70.04 \%$ of Indian grey hornbills were sighted from 2001 to 2013 at spot 4.

Indian grey hornbill population recorded during breeding season in all the four spots is given in Table 1 and the average population for 20 years is shown in Table 2.

\begin{tabular}{|c|c|c|c|c|c|c|c|c|c|c|c|}
\hline Month & Year & Spots & & & & Month & Year & Spots & & & \\
\hline & & 1 & 2 & 3 & 4 & & & 1 & 2 & 3 & 4 \\
\hline March & 1994 & 9 & 11 & 2 & 2 & March & 2004 & 16 & 0 & 2 & 22 \\
\hline April & & 9 & 12 & 0 & 0 & April & & 18 & 0 & 2 & 26 \\
\hline May & & 8 & 11 & 1 & 1 & May & & 17 & 1 & 1 & 16 \\
\hline June & & 9 & 11 & 1 & 2 & June & & 12 & 0 & 2 & 14 \\
\hline July & & 10 & 10 & 0 & 0 & July & & 15 & 1 & 2 & 17 \\
\hline March & 1995 & 12 & 12 & 2 & 2 & March & 2005 & 15 & 0 & 1 & 15 \\
\hline April & & 14 & 14 & 2 & 2 & April & & 14 & 0 & 0 & 18 \\
\hline May & & 10 & 8 & 0 & 2 & May & & 17 & 0 & 2 & 17 \\
\hline June & & 11 & 7 & 2 & 1 & June & & 16 & 1 & 2 & 16 \\
\hline July & & 12 & 9 & 0 & 0 & July & & 18 & 0 & 1 & 18 \\
\hline March & 1996 & 14 & 13 & 3 & 3 & March & 2006 & 19 & 0 & 0 & 13 \\
\hline April & & 12 & 11 & 2 & 0 & April & & 20 & 1 & 0 & 12 \\
\hline May & & 18 & 13 & 0 & 1 & May & & 22 & 1 & 2 & 16 \\
\hline June & & 16 & 13 & 1 & 1 & June & & 20 & 2 & 2 & 15 \\
\hline July & & 15 & 12 & 1 & 1 & July & & 20 & 0 & 2 & 16 \\
\hline March & 1997 & 11 & 12 & 2 & 2 & March & 2007 & 18 & 1 & 0 & 14 \\
\hline April & & 13 & 13 & 1 & 0 & April & & 19 & 2 & 0 & 12 \\
\hline May & & 14 & 13 & 0 & 2 & May & & 16 & 1 & 0 & 12 \\
\hline June & & 12 & 12 & 1 & 1 & June & & 22 & 2 & 0 & 13 \\
\hline July & & 17 & 13 & 2 & 1 & July & & 20 & 0 & 2 & 14 \\
\hline March & 1998 & 14 & 14 & 0 & 0 & March & 2008 & 16 & 2 & 1 & 12 \\
\hline April & & 12 & 11 & 1 & 1 & April & & 16 & 1 & 1 & 11 \\
\hline May & & 14 & 13 & 1 & 1 & May & & 18 & 0 & 0 & 10 \\
\hline June & & 13 & 13 & 1 & 0 & June & & 15 & 2 & 0 & 11 \\
\hline July & & 15 & 11 & 0 & 0 & July & & 17 & 1 & 0 & 15 \\
\hline March & 1999 & 12 & 12 & 1 & 0 & March & 2009 & 18 & 0 & 2 & 16 \\
\hline April & & 12 & 12 & 0 & 0 & April & & 16 & 0 & 2 & 14 \\
\hline May & & 13 & 13 & 2 & 2 & May & & 17 & 0 & 1 & 12 \\
\hline June & & 11 & 14 & 1 & 1 & June & & 19 & 0 & 1 & 12 \\
\hline July & & 12 & 13 & 2 & 2 & July & & 20 & 0 & 1 & 12 \\
\hline
\end{tabular}


Citation: Birasal NR (2014) Density of Indian Grey Hornbills (Ocyceros birostris) in and Around Haveri. J Biodivers Biopros Dev 1: 110. doi:

Page 4 of 6

\begin{tabular}{|c|c|c|c|c|c|c|c|c|c|c|c|}
\hline March & 2000 & 13 & 12 & 2 & 2 & March & 2010 & 19 & 1 & 0 & 18 \\
\hline April & & 12 & 12 & 1 & 1 & April & & 20 & 2 & 2 & 12 \\
\hline May & & 13 & 11 & 2 & 1 & May & & 18 & 1 & 2 & 12 \\
\hline June & & 12 & 13 & 2 & 2 & June & & 19 & 2 & 1 & 14 \\
\hline July & & 12 & 14 & 0 & 0 & July & & 19 & 1 & 0 & 15 \\
\hline March & 2001 & 12 & 2 & 0 & 10 & March & 2011 & 2 & 1 & 10 & 16 \\
\hline April & & 14 & 2 & 1 & 12 & April & & 5 & 2 & 12 & 14 \\
\hline May & & 14 & 1 & 1 & 12 & May & & 6 & 1 & 11 & 14 \\
\hline June & & 16 & 2 & 0 & 16 & June & & 4 & 2 & 12 & 12 \\
\hline July & & 15 & 3 & 1 & 13 & July & & 3 & 1 & 12 & 12 \\
\hline March & 2002 & 12 & 0 & 1 & 13 & March & 2012 & 2 & 1 & 14 & 14 \\
\hline April & & 13 & 0 & 1 & 14 & April & & 2 & 1 & 16 & 14 \\
\hline May & & 13 & 0 & 2 & 12 & May & & 1 & 1 & 12 & 12 \\
\hline June & & 12 & 1 & 2 & 12 & June & & 3 & 2 & 12 & 13 \\
\hline July & & 12 & 1 & 2 & 14 & July & & 4 & 1 & 12 & 13 \\
\hline March & 2003 & 15 & 2 & 2 & 16 & March & 2013 & 1 & 1 & 16 & 15 \\
\hline April & & 15 & 1 & 1 & 15 & April & & 2 & 0 & 16 & 12 \\
\hline May & & 15 & 2 & 1 & 16 & May & & 1 & 2 & 14 & 12 \\
\hline June & & 16 & 1 & 0 & 14 & June & & 2 & 1 & 12 & 14 \\
\hline July & & 16 & 2 & 0 & 12 & July & & 2 & 1 & 15 & 16 \\
\hline
\end{tabular}

Table 1: Indian Grey Hornbill population records at 4 spots.

\begin{tabular}{|l|l|l|l|l|l|}
\hline \multirow{2}{*}{ SI.No } & \multirow{2}{*}{ Year } & \multicolumn{4}{|l|}{ Spots } \\
\cline { 3 - 6 } & & $\mathbf{1}$ & $\mathbf{2}$ & $\mathbf{3}$ & $\mathbf{4}$ \\
\hline 1 & 1994 & 45 & 55 & 4 & 5 \\
\hline 2 & 1995 & 59 & 50 & 6 & 7 \\
\hline 3 & 1996 & 75 & 62 & 7 & 6 \\
\hline 4 & 1997 & 67 & 63 & 6 & 6 \\
\hline 5 & 1998 & 68 & 62 & 3 & 2 \\
\hline 6 & 1999 & 60 & 64 & 6 & 5 \\
\hline 7 & 2000 & 62 & 62 & 7 & 6 \\
\hline 8 & 2001 & 71 & 10 & 3 & 63 \\
\hline 9 & 2002 & 62 & 8 & 8 & 65 \\
\hline 10 & 2003 & 77 & 4 & 4 & 73 \\
\hline 11 & 2004 & 78 & 2 & 9 & 95 \\
\hline 12 & 2005 & 80 & 1 & 6 & 84 \\
\hline 13 & 2006 & 101 & 4 & 6 & 72 \\
\hline
\end{tabular}

\begin{tabular}{|l|l|l|l|l|l|}
\hline 14 & 2007 & 95 & 6 & 2 & 65 \\
\hline 15 & 2008 & 82 & 6 & 2 & 59 \\
\hline 16 & 2009 & 90 & 0 & 7 & 66 \\
\hline 17 & 2010 & 95 & 7 & 5 & 71 \\
\hline 18 & 2011 & 20 & 7 & 57 & 68 \\
\hline 19 & 2012 & 12 & 6 & 66 & 66 \\
\hline 20 & 2013 & 8 & 5 & 73 & 69 \\
\hline
\end{tabular}

Table 2: Average number of Indian Grey Hornbill population recorded in four spots of Haveri district for 20 years.

The town though elevated to district headquarter status on August 24, 1997 has still several old Ficus trees. Thanks to district administration for not razing those in the name of development. Indian Grey hornbills are now feeding on the fruits of the plants like Ficus bengalensis (banyan), Ficus religiosa (papal) and Ficus carica (anjri) in and around Haveri town (Figure 2). 


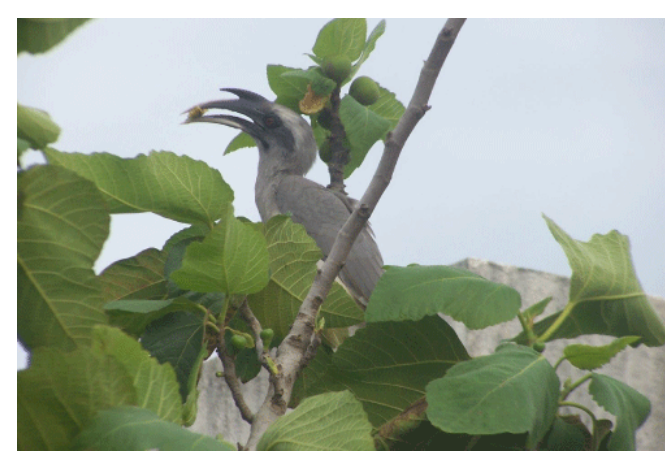

Figure 2: Indian Grey Hornbill relishing the fleshy-pulpy edible receptacle of Ficus carica found in the gardens of Haveri town.

\section{MAP SHOWING THE FOUR SPOTS WHERE REGULAR VISITS WERE CARRIED OUT}

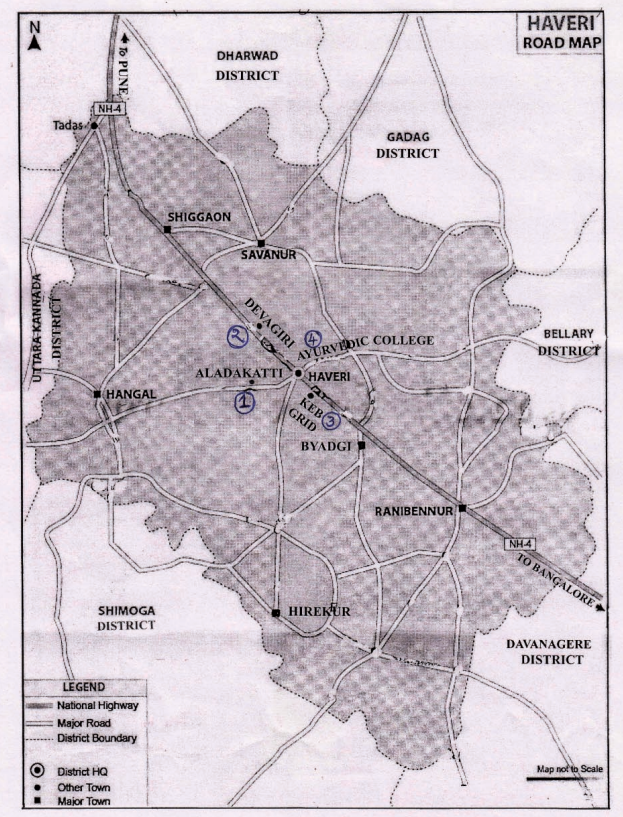

From 1994 to 2010, hornbills observed at spot 1 were found sitting on Syzygium cumini / Eugenia jambolana. Indian Grey Hornbills were feeding on pulpy - juicy purple dark blue coloured berry fruits at this site. Hornbills observed at spot 2 from 1994 to 2000 were feeding on firm-pulpy-sweet eril (legume) pods of Pithecolobium dulce. The regular perching sites of Indian Grey hornbills in and around Haveri town are the tree trunks of Delonix regi, Tamarindus indica (Caesalpinaceae), Azadirchta indica, Melia azedarachta (Meliaceae) and Capparis grandis.

During the 20 years study period, author has noticed nesting behaviour only in 2009 at spot 1 . Both the male and female hornbills were noticed peeping into tree cavities, one after the other. This was often noted and continued until the female entering into the nest cavity found on the tree trunk of Ficus bengalensis.

Female entered the cavity in only one nest on March 1, 2009. As soon as female entered the cavity, she started cleaning the nest and it was observed 'her throwing out all the waste materials left in by the previous user'. Male was also entering the nest cavity to take out loose material, probably to remove nesting material collected by Rose ringed Parakeets (Psittacula krameri) and common Mynas (Acridothere tristis). These are the common birds in the study area and occupy the cavities of the hornbill nest as soon as they vacate it after the fledging of the chicks.

When the author visited the same spot on April 5, 2009, he could notice the sealed nest cavity. The male was busy in bringing fruits of Ficus bengalensis towards the nest to feed female and this was noticed during the visit made on May 3, 2009. Both male and female hornbills were busy in visiting the nesting site to feed the chicks during the visit made on June 7, 2009. During the visit on July 5, 2009 it was observed that 2 chicks making calls and sitting in the top branches of the nest tree with the adult female. Poaching of Indian grey hornbills was not recorded in any site during the study period.

\section{Discussion}

Hornbills are globally threatened by habitat loss, fragmentation and hunting [15]. It is reported that endemic passerine species may become vulnerable to extinction in areas where habitat destruction is extensive [13]. Out of 45 localities visited in Western ghats across five states like Maharashtrea, Goa, Karnataka, Kerala and Tamilnadu, 12 individuals of Indian grey hornbill were seen only in 2 locations in the total survey length of $286.4 \mathrm{~km}$ [16]. Nest tree use and breeding behaviour of Indian grey hornbill is recorded in Sathyamangalam forest area of Eastern Ghats [7]. Breeding behaviour of Indian grey hornbill is also reported from urban environment in Nagpur city of central India [8]

Studies on Indian grey hornbill in Sathyamangalam forest area have revealed that tree species and food plant species that harbour require nest and are very crucial for the survival of Indian Grey hornbill in Eastern Ghats [9]. Habitat destruction of Indian grey hornbills is noticed in the first two spots and this coincided with very less number of hornbills. Interestingly, the roadside trees of Haveri town which were harbouring very few numbers of hornbills before destruction of trees on highways are now showing higher population of these arboreal birds. The present study indicates the need for protection of hornbill habitats from human interferences.

\section{Conservation implications:}

Dandeli forest (52.50 Sq.Kms including both Joyda and Haliyal talukas in Uttara Kannada district) is the home to four types of hornbills viz; Malabar Pied, Malabar Grey, Great Pied and Indian Grey. These birds are the residents in Dandeli forest and over a hundred roosts (a branch of a tree, where birds rest or sleep). Government on May 31, 2011 declared the Dandeli forest as Hornbill conservation reserve under Section 36(A) of the Wildlife Protection Act 1972.

Uttara Kannada district is the adjoining district for Haveri. Now the trees harbouring hornbills on road sides of Haveri have been razed in the name of development. In order to save and encourage the increase 
Citation: Birasal NR (2014) Density of Indian Grey Hornbills (Ocyceros birostris) in and Around Haveri. J Biodivers Biopros Dev 1: 110. doi: $10.4172 / 2376-0214.1000110$

Page 6 of 6

in the population of Indian Grey hornbills in Haveri town, the district administration needs to ban cutting down of old trees.

\section{Acknowledgements}

This study is financially supported by University Grants Commission (Vide MRP(S) - 89 / 2004 / KAKA081 / UGC - SWRO dated 18.03.2004 and MRP(S)-85/12-13/KAKA 081/UGC-SWRO dated 29.03.13). Sincere thanks to Honourable Chairman of KLE Society Belgaum Dr. Prabhakar Kore, Members of the board of management, Principal Dr. B C Bannur for their support.

\section{References}

1. Kemp AC (2001) Family Bucerotidae (Hornbills) Pp 436 - 523. In J de Hoyo, A Elliott and J Sargatal Eds. Handbook of the birds of the world. 3 Barcelona: Lunx edition.

2. Ali S, Ripley SD (1987) Compact handbook of the Birds of India and Pakistan together with those of Bangladesh, Nepal, Bhutan and Srilanka. Oxford University press, New Delhi 286.

3. Ali S (2002) The book of Indian birds. 13th edition. Oxford university press, New Delhi.

4. Balasubramanian P, Ravi R, Venkitachalam R, Maheshwaran BH, Krishnakumar N, et al. (2007) Status and conservation of the hornbills in Southern India Pp 143 - 153. In : Kemp A C and Kemp M I (Eds). The active management of hornbills and their habitat for conservation. CDROM. Proceedings of the 4th International Hornbill conference. Naturalists \& Nomada, Pretoria: Mabula Game Lodge, Bela-Bela, South Africa.

5. Kemp, AC (1978) A review of the hornbills biology and radiation. Living Bird 17: 105-136.
6. Kemp AC (1995) The Hornbills : Bucerotiformes. Oxford university press, Oxford, 302.

7. Santhoshkumar E, Balasubramanian P (2010) Breeding behaviour and nest tree use by Indian Grey Hornbill Ocyceros birostris in the Eastern Ghats. India Forktail 26: 82-85.

8. Praveen Charde, Raju Kasambe, Jeevan L Tarar (2001) Breeding behaviour of Indian grey hornbill in central India. The Raffles bulletin of zoology supplement 24: 59-64.

9. Balasubramanian Paramasivam, Easwaran Santhoshkumar, Chinnasamy Anbarasu (2011) Vegetation features and restoration initiatives in the Indian grey hornbill habitats in Sathyamangalam wildlife sanctuary, eastern ghats, India. The Raffles bulletin of zoology supplement 24: 5357.

10. Ullas Karanth K (1981) Bhadra wildlife sanctuary and its endangered ecosystem. Bombay Natural History Society 79: 79-86.

11. Kannan R (1994) Ecology and conservation of the Gtreat pied hormbill (Buceros bicornis) in the western ghats of south India. Ph.D dissertation, Universitu of Arkanas: 157.

12. Salim Ali (1936) Economic ornithology in India. Current science, $472-$ 478 .

13. Dhindsa Manjit, Harjeet K Saini (1994) Agricultural ornithology: an Indian perspective. J.Biosci, 4: 391-402.

14. Ali S , Ripley SD (1983) Handbook of the Birds of India and Pakistan, together with those of Bangladesh, Nepal, Bhutan and Sri Lanka. Oxford University press, New Delhi: 488.

15. Vijaykumar Sneha, Priya Davidar (2011) Status survey of the Malabar pied hornbill in Dandeli region, Northern Western Ghats, India. The Raffles bulletin of zoology supplement 24: 45-51.

16. Divya Muddappa, Shankar Raman T R (2009) A conservation status survey of hornbills (Bucerotidae) in the Western Ghats, India. Indian Birds 5: 90-102. 